\title{
What Should Graduates from Elementary Schools Know About Geography
}

\section{Isaac O. Winslow}

To cite this article: Isaac O. Winslow (1904) What Should Graduates from Elementary Schools Know About Geography, Journal of Geography, 3:10, 458-462, DOI:

10.1080/00221340408985553

To link to this article: http://dx.doi.org/10.1080/00221340408985553

册 Published online: 12 May 2008.

Submit your article to this journal $₫$

Џll Article views: 6

Q View related articles $\widetilde{ }$ 


\title{
WHAT SHOULD GRADUATES FROM ELEMEN. TARY SCHOOLS KNOW ABOUT GEOGRAPHY
}

\author{
BY ISAAC O. WINSLOW \\ Principal of Thayer Street School, Providence, R. I.
}

$\mathrm{T}$ $\mathrm{HE}$ determination of the course in geography for elementary schools is a process of selection and elimination. In the rapid development of the subject in recent years a great amount of the "new geography" has been added, while but little of the old has been abandoned. The result is that we have an impossible amount of subject-matter included in the course and in the textbooks, and the attempt to accomplish the whole leads to confusion. The necessity of selecting imposes an unnecessary burden upon the ordinary teacher and requires greater ability than she possesses. The few artist teachers are able to shape their own work, but while we are theorizing about the few we are neglecting the many.

Of all the work that might be regarded as belonging in the geographical sphere of education, to determine what parts are of greatest worth to the average child as a preparation for life is the task that lies before us. There ought to be a more general agreement with regard to the several divisions of geography-astronomical, mathematical, physical, historical, political, descriptive, and economic-upon the question what there is in each division that for its practical utility, or its value in culture, the average child should be expected to know at the time of leaving the elementary schools.

With regard to astronomical and mathematical conceptions, too much is generally expected of young children and but little is accomplished. By the simplest forms of illustration, with the globe and a diagram, and by observations of the sun, the most elementary notions of the motions of the earth and its relative positions should be thoroughly established in the mind of the child as a permanent possession. Upon this basis he should be able to understand the causes of the changes of the seasons, the alternation of day and night, and the variation in the length of the days. A little practice in thinking where the sun would appear to be in the heavens, at noon, to one situated at the equator, at the tropical circles, at the Arctic Circle, and in various countries of the world, at different seasons of 
the year, will serve to effect a transition from the artificial illustrations to an imagination of the realities.

There is great danger of attempting too much in physical geography and of teaching it at the wrong time. Pupils of the high school grade may find interest in this part of the subject, when pursued for its own sake and with extended applications in detail, but for elementary pupils this is wearisome and unprofitable. It is not difficult, however, to awaken an interest in scientific principles and facts which can be easily understood and which have an evident relation to human welfare. A good understanding of such elementary principles is necessary as a general basis for causal explanations. In setting forth these principles it is not necessary to give all the causes that produce a given effect. A clear idea of one cause is better than a confused notion of several, and satisfies the demand for explanation.

We should give a clear idea of the cause of the movement of the air, in general, and of some particular applications, such as sea breezes and land breezes. The latter part of the course should include an explanation of the prevailing winds of the earth and their changes with the seasons.

With regard to temperature, two points are important, the difference due to elevation, and the difference between inland regions and those near large bodies of water. An explanation of the curves in isothermal lines, at various seasons, furnishes good practice in the application of these principles.

The child should be able to give, first, the general causes of the appearance of moisture in the atmosphere in the form of fog, mist, clouds, and rain, and secondly, the most common of the particular causes, as when a body of air rises, or passes over mountains, and when the trade wind meets the land. These points should be so thoroughly understood that an application may be readily made under any specified conditions.

A causal explanation of the physical features of the earth requires a brief account of geological history, including the formation of the earth's crust by cooling, the principal agencies of erosion, the formation of new strata, the effects of upheaval and depression, volcanic action, the effects of rivers in wearing down their beds, transporting detritus, and forming flood plains and deltas, the work of waves on the coast, and the principal effects of the Ice Sheet. It is impossible to avoid an elementary consideration of these principles without abandoning the attempt to give explanation and reverting to a static 
treatment of geography, or mere description. On the other hand it is necessary to guard against the temptation to enter into details too minutely. Brief and simple explanations, if clear and correct as far as they go, are not open to the charge of superficiality.

The aspect of supreme importance, to which mathematical and physical considerations are subordinate and in which the highest interest of children centers, is the treatment of the people of the earth, of the geographical reasons for their activities, and of the causes and results of their abode in the various regions.

As an introduction to the life of the people of a country and as a means of awakening interest in them, it is of great advantage to give a brief account of their origin and of the development of their leading characteristics. A brief statement of the great national facts in the history of the Swiss people, for example, an account of their patriotism and their struggle for liberty and independence, arouses an interest in their present conditions as nothing else can.

The culmination of both interest and value is in the customs and occupations of the people, especially as resulting from natural conditions. Children are eager to learn what manner of life the people of a country are leading, what they are doing and why they are doing it. A strict regard for the limits of the field would confine us to such activities of the people as are geographically determined, but it is unnecessary to be greatly troubled upon that point. The objection to passing beyond the boundary lines has a stronger basis in the question of economy of time, than in that of sinning against principles. The teacher himself should have so clear a view as to know the boundaries of the field, but should not hesitate, at times, to pass beyond them. The production of wheat in the Dakotas and Minnesota is a fact geographically determined. Routes of transportation of the wheat, if affected by geographical conditions, are also legitimate. The water power at Minneapolis may furnish an excuse for mentioning the bare fact that wheat is there converted into flour. Precise geographers of a certain type are ready to cry out against anything further, and yet the practical teacher who fails to weave in details by briefly describing the methods of handling the wheat and the process of manufacturing flour, misses an easy opportunity to clothe the subject with life and to strengthen the memory by vividness.

The commercial phases of geography belong preëminently in the elementary course. To account for the leading productions of a 
country without explaining what becomes of them is to leave the thought in suspense. A study of the system of exchanges of the great staple products among the various countries is as easy and interesting as the spontaneous play of childhood. Thorough practice in thinking out the leading commercial routes and the products transported over them serves as the best kind of final review and fixes in mind a most concise knowledge of world relations. Recently there has been a tendency to enlarge upon physical geography in the elementary schools while, on the other hand, commercial geography has generally been regarded as a high-school subject. There are good reasons for reversing this. The graduate from the elementary schools should be sufficiently acquainted with the practical world of the present day to have in mind a fairly complete scheme of commercial relations and exchanges. On the other hand, with a good understanding of the simplest elements of physical geography he can afford to postpone an elaborate treatment of that subject.

Such an industrial and commercial view of the world will serve to emphasize the most important part of "sailor geography." Mere convenience requires one to be familiar with minor localities in the vicinity of his home and within the circuit of his practical life, but aside from this the indiscriminate cramming of names and locations is worse than useless.

Since the capital cities are rot always the largest cities of countries and states, there is neither practical nor disciplinary value in the ability to recite them. The memory should not be burdened with the names of more cities than are often mentioned in the newspapers or in books commonly read. Every city of this class should be associated, in the child's mind, with some special industry or attraction for which it is noted.

Great exactness should not be required in the matter of locations or boundaries, except in the case of the home state or country. The ability to name, in order, the succession of states along the border of the country or along a river, or those through which one would pass in traveling from a given point in a given direction, embraces all that is of much value in this kind of knowledge. If children can give the countries and the parts of the countries in which the important mountain ranges and rivers are situated, there is little additional advantage in more exact details. The knowledge of capes, gulfs, and bays and other forms on the coast should be confined to those whose names are of frequent occurrence. The most effectual means of fixing locations 
in the memory is practice in filling outline maps, or making maps quickly from memory.

The suggestions herein set forth may seem to propose a course unnecessarily brief and simple, but they will be appreciated by those who have had experience in ascertaining how little of all the geography that is studied in school is retained in after life. It is true of many subjects of study that much is gained from what has been once learned and for the time forgotten, but in geography facts forgotten are nearly a total loss. In this department it is best to strive to know the few things well.

\title{
COMMERCIAL IMPORTANCE OF CON- TINENTS *
}

\author{
BY GEO. D. HUBBARD \\ Cornell University
}

$\Lambda^{\mathrm{F}}$

FRICA has been styled by a leading traveler, "The Coming Continent." In what sense may it be thus named? Perhaps because of its rapid development; perhaps because many European nations rushed precipitously, less than two decades ago, to possess themselves of a portion. Certainly not as a place into which the peoples of temperate climes may overflow, since most of the great continent is climatically unfitted to be their home. Certainly not for its people, because its unnumbered millions belong to low, savage, restless, workless, or nomadic, marauding types. And certainly not on account of its mineral wealth, although the output of gold and diamonds is something prodigious, because these minerals never have been the basis of the permanent development of any country, nor indeed can be. The nations whose greatness is due to mineral industries base them on coal and iron. Certainly not as a market for manufactured articles because most of the natives, who constitute a large percentage of the $130,000,000 \dagger$ souls, make all the clothing and tools for which they have use. Wherein, then, lies

*Note.-After the continents have all been studied it is well to sum up the work in various ways, and to introduce comparisons and contrasts between them as to size, population, position, and other characteristics. The theme of the accompanying paper may be suggestive along this line. The countries of a continent or states of a nation may serve as a basis for a similar study.

$\dagger$ A mean of the estimates for Africa's population. 